\title{
ІНФОРМАЦІЙНІ ТЕХНОЛОГІЇ ЯК ІНСТРУМЕНТ ПОБУДОВИ ІНТЕГРОВАНОЇ ЛОГІСТИЧНОЇ СИСТЕМИ В ОРГАНІЗАЦІЇ МЕДИЧНОГО ПОСТАЧАННЯ ЗБРОЙНИХ СИЛ УКРАЇНИ
}

\author{
М. В. Білоус, О. А. Рижов, О. П. Шматенко ${ }^{1}$, Д. В. Дроздов ${ }^{1}$ \\ Запорізький державний медичний університет \\ ${ }^{1}$ Українська військово-медична академія
}

Визначена необхідність побудови інтегрованої логістичної системи на базі сучасних інформаційних технологій для оптимізації медичного постачання збройних Сил України.

\section{INFORMATION TECHNOLOGY AS A TOOL FOR BUILDING AN INTEGRATED LOGISTICS SYSTEMS IN MEDICAL SUPPLY OF ARMED FORCES OF UKRAINE}

\author{
M. V. Bilous, O. A. Ryzhov, O. P. Shmatenko ${ }^{1}$, D. V. Drozdov ${ }^{1}$ \\ Zaporizhzhya State Medical University \\ ${ }^{1}$ Ukrainian Military Medical Academy
}

\begin{abstract}
The necessity of integrated logistics systems building on base of modern information technologies for the optimization of the medical supply of Armed Forces of Ukraine is defined.
\end{abstract}

Вступ. Оптимізація управління потоковими процесами в Збройних Силах України (ЗСУ), в тому числі і в системі медичного постачання, наразі є одним з ключових питань і потребує детального вивчення та удосконалення. Використання сучасних інформаційних технологій є пріоритетним напрямком для забезпечення оптимізації логістичного управління у системі військової охорони здоров'я.

Мета дослідження полягає в аналізі, узагальненні, окресленні основних інструментів побудови інтегрованих логістичних систем на базі інформаційних технологій в організації медичного постачання в ЗСУ.

Матеріали і методи дослідження. Для досягнення мети дослідження проведено системний аналіз світових і вітчизняних наукових джерел. Методами дослідження є бібліографічний, аналітичний і системного аналізу.

Результати й обговорення. Сьогодні у системі військової охорони здоров'я, а саме в організації медичного постачання ЗСУ, ефективність управління потоковими процесами залежить від якісного функціонування логістичної системи (ЛС). Традиційним призначенням логістики є: забезпечення наявності потрібного продукту в необхідній кількості та заданої якості в потрібному місці у встановлений час для конкретного споживача 3 найкращими витратами.

Організація медичного логістичного забезпечення ЗСУ має свої особливості. Воно повинно бути надійним, здатним забезпечити оперативне постачання медичного майна як за територіальним принципом так і вразі необхідності в межах всього театру бойових дій. Разом з тим, медичне майно потребує впровадження системи сурового контролю та спеціалізованого управління. Причинами цьому є обмежений термін зберігання медичного майна, висока чутливість до умов зберігання та транспортування.

Останніми роками все більшого поширення набуває концепція інтегрованої логістики, чому сприяв кращій світовий і вітчизняний досвід оптимізації потокових процесів у фармацевтичній галузі. Ï̈̈ суть полягає в узгодженні та збалансованості всіх взаємопов'язаних видів логістичної діяльності (логістика постачання, виробництва, розподілу, складування, транспортування в логістичних системах), таким чином, що вони мають виконуватися у вигляді єдиного процесу, зберігання та переміщення матеріальних ресурсів, який спрямований на оптимізацію всіх логістичних

\footnotetext{
(c) М. В. Білоус, О. А. Рижов, О. П. ІШматенко, Д. В. Дроздов
} 
операцій для досягнення максимально ефективних часових критеріїв постачання медичного майна в ЗСУ, особливо під час ведення активних бойових дій. Наразі управління логістичними операціями, функціями та функціональними областями у ЛС здійснюється на базі інформаційних технологій та відповідного комплексу технічних засобів. А для функціонування інтегрованої ЛС необхідна інформаційна система, що охоплює усі види логістичної діяльності - декілька логістичних ланцюгів, тобто побудова інтегрованого логістичного ланцюга. Зараз виникла необхідність до переходу від простої автоматизації складових логістичного ланцюга до інтеграції та координації всіх процесів в ланцюзі постачання медичного майна. Існує безліч базових концепцій (технологій) логістики: RP (Requirements/resource planning) - Планування потреб/ ресурсів; JIT (Just-in-time) - Точно у термін; TBL (Time-based logistics) - Логістика, що орієнтована на час; QR (Quick response) - Метод швидкого реагування та інші. Вибір найбільш відповідної логістичної технології залежить від логістичної стратегії, розробка якої здійснюється у чотири етапи: оцінка, аналіз можливостей, встановлення пріоритетів, виконання. Наступним етапом побудови інтегрованої ЛС є конфігурація логістичної системи, ідентифікація ключових логістичних процесів, формування організаційної структури та системи контролінгу логістики, вибір інформаційної підтримки та баз даних логістичних операцій. Слід відмітити, що без інформаційної інтеграції не можлива побудова єдиного інформаційного простору ланцюга. Інформаційна інтеграція дозволяє забезпечити необхідну в сучасних умовах швидкість, повноту та точність отримання відомостей, потрібних для надання логістичних послуг.

Висновки. Побудова та впровадження інтегрованої ЛС у систему медичного постачання 3СУ на базі сучасних інформаційних технологій є необхідністю для оптимізації управління потоковими процесами. Це підвищить ефективність, своєчасність, надійність та прозорість логістичної діяльності військово-медичної служби України. 